Sri Wahyuni ${ }^{1}$

Rizki Ananda ${ }^{2}$

Rusdial Marta ${ }^{3}$

\section{PENINGKATAN KETERAMPILAN MENULIS KARANGAN DENGAN MENGGUNAKAN MEDIA GAMBAR PADA SISWA KELAS V SEKOLAH DASAR}

\begin{abstract}
Abstrak
Penelitian ini bertujuan untuk meningkatan keterampilan menulis karangan dengan menggunakan media gambar pada siswa Kelas V SDN 004 Bangkinang Kota. Penelitian Tindakan Kelas (PTK) yang dilaksanakan dalam dua siklus. Setiap siklus terdiri dari satu pertemuan dan empat tahapan, yaitu perencanaan, tindakan, pengamatan dan evaluasi, refleksi. Hasil penelitian ini diketahui persentase dalam menulis karangan dengan menggunakan media gambar meningkat. Siklus I aspek A (ide yang dikemukakan dalam menulis karangan itu sudah tepat) $58,82 \%$, aspek B (sistem penulisan sudah benar atau perlu perbaikan) $63,52 \%$, aspek C (karangan itu bertele-tele atau terlalu simple) 65,88\%, aspek D (penggunaan bahasanya cukup baik atau tidak) $83,52 \%$, aspek E (judul menulis karangan itu sudah tepat atau tidak) 87,05\%. Sedangkan siklus II terjadi peningkatan setiap aspek yaitu aspek A (ide yang dikemukakan dalam menulis karangan itu sudah tepat) yaitu 68,23\%, aspek B (sistem penulisan sudah benar atau perlu perbaikan) yaitu 70,58\%, aspek C (karangan itu bertele-tele atau terlalu simple) yaitu $76,47 \%$, aspek D (penggunaan bahasanya cukup baik atau tidak) yaitu $94,11 \%$ aspek E (judul menulis karangan itu sudah tepat atau tidak ) yaitu 95,29\%. Dengan demikian dapat disimpulkan bahwa dengan menggunakan media gambar dapat meningkatkan keterampilan menulis karangan siswa kelas V SDN 004 Langgini, Bangkinang Kota.
\end{abstract}

Kata Kunci: Menulis Karangan, Media Gambar

\begin{abstract}
This study aims to improve the writing skills of essays by using media images in Class $\mathrm{V}$ students of SDN 004 Bangkinang Kota. Classroom Action Research (CAR) is carried out in two cycles. Each cycle consists of one meeting and four stages, namely planning, action, observation and evaluation, reflection. The results of this study note that the percentage in writing essays using image media increases. Cycle I aspect A (the idea put forward in writing the essay is correct) $58.82 \%$, aspect B (writing system is correct or needs improvement) $63.52 \%$, aspect C (the essay is wordy or too simple) $65,88 \%$, aspect $\mathrm{D}$ (use of the language is good enough or not) $83.52 \%$, aspect $\mathrm{E}$ (the title of writing the essay is correct or not) $87.05 \%$. While the second cycle increased every aspect, namely aspect A (the ideas put forward in writing the essay were correct)

\footnotetext{
${ }^{1}$ Pendidikan Guru Sekolah Dasar, Fakultas Ilmu Pendidikan, Universitas Pahlawan Tuanku Tambusai Alamat email Sriwahyunipgsd5@gmail.com

${ }^{2}$ Pendidikan Guru Sekolah Dasar, Fakultas IImu Pendidikan, Universitas Pahlawan Tuanku Tambusai Alamat email rizkiananda.mhs.upi@gmail.com

${ }^{3}$ Pendidikan Guru Sekolah Dasar, Fakultas IImu Pendidikan, Universitas Pahlawan Tuanku Tambusai Alamat email dial.fredo90@gmail.com
} 
namely $68.23 \%$, aspect B (the writing system was correct or needed to be improved) namely $70.58 \%$, aspect $\mathrm{C}$ (the essay was written) -tele or too simple) that is $76.47 \%$, aspect $\mathrm{D}$ (use of the language is good enough or not) that is $94.11 \%$ aspect $\mathrm{E}$ (the title of writing the essay is correct or not) that is $95.29 \%$. Thus it can be concluded that by using media images can improve the writing skills of students in class V SDN 004 Langgini, Bangkinang Kota.

Keywords: Writing Essays, Image Media 


\section{PENDAHULUAN}

Bahasa Indonesia adalah salah satu mata pelajaran yang harus dikuasai oleh siswa, untuk meningkatkan keterampilan dalam Bahasa Indonesia yang meliputi keterampilan menyimak, berbicara dan menulis. Karena disamping sebagai bahasa nasional juga merupakan mata pelajaran yang menentukan kelulusan. Sejak taman kanak-kanak siswa sudah diperkenalkan dengan Bahasa Indonesia. Banyak siswa yang menganggap mudah belajar Bahasa Indonesia karena Bahasa Indonesia merasa sudah dikuasainya sejak kanak-kanak.

Mengingat pentingnya Bahasa Indonesia, maka pembelajaran harus dilaksanakan secara maksimal. Keberhasilan kegiatan belajar mengajar sangat ditentukan berbagai faktor yang berkaitan dengan proses belajar mengajar. Kunci utama dalam memajukan pendidikan adalah guru. Guru harus mampu menggunakan berbagai macam strategi pembelajaran agar proses pembelajaran lebih manarik dan menyenangkan.

Berdasarkan observasi awal pada tanggal 5 Maret 2018 yang peneliti laksanakan di SDN 004 Bangkinang Kota pada mata pelajaran Bahasa Indonesia khususnya di Kelas V SDN 004 Bangkinang Kota, bahwa masih dijumpai beberapa gejala-gejala yang menyebabkan rendahnya belajar menulis siswa terutama pada mata pelajaran Bahasa Indonesia. Seperti, (1) kurangnya minat menulis siswa dalam proses pembelajaran Bahasa Indonesia. (2) guru hanya berfokus pada 1 sumber buku paket atau 1 informasi saja tidak melibatkan lingkungan dan menjadikan siswa tidak mendapatkan informasi yang bnyak. (3) guru menggunkan metode yang berpariatif dan inofatif, didominasi oleh metode konvensional (ceramah). (4) mengerjakan, siswa tidak dapat berkerjasama dalam kelompok karena meraka tidak bisa diatur hanya bermain.

Hasil pengamatan di kelas V SDN 004 Bangkinang Kota kenyataan bahwa menulis karangan tidak diperoleh secara spontan, dengan hasil observasi pada umumnya siswa disekolah tersebut kurang terampil dalam menulis karangan pada pembelajaran Bahasa Indonesia karena siswa kurang mampu dalam memilih kata dan menuang buah pikirnya, disamping itu siswa yang mengikuti pelajaran kurang bersemangat karena guru kurang melibatkan siswa dalam proses belajar mengajar, sehingga siswa kurang aktif dalam pembelajaran menulis. Kalimat yang satu dengan yang lainnya tidak bersinambungan, paragraf yang satu dengan yang lainnya tidak koheren. Dari hasil observasi, peneliti juga menemukan fakta bahwa guru menggunakan media yang sifatnya kreatif dan inovatif dalam proses belajar mengajar yang melibatkan aktivitas mental, fisik dan emosional.

Berdasarkan wawancara yang peneliti lakukan, dalam pembelajaran Bahasa Indonesia keterampilan menulis karangannya masih rendah. Ketika guru memberikan tugas menggunakan media gambar siswa mampu melaksanakannya tapi hanya bisa menceritakan sedikit saja apa yang ada digambar tersebut. Siswa belum mampu menjabarkan karangannya kearah yang lebih luas. Sehingga dibutuhkan suatu media yang mendorong siswa untuk menulis karangan.

Berdasarkan uraian di atas dapat disimpulkan bahwa keterampilan menulis karangan dalam pembelajran Bahasa Indonesia masih rendah pada siswa kelas $\mathrm{V}$ yang berjumlah 22 orang adalah 6,35 yang seharusnya nilai rata-rata yang menjadi kriteria ketuntasan minimal (KKM) adalah 75. Alasan dari perolehan nilai tersebut adalah bahwa pembelajaran menulis karangan kurang termotivasi siswa dalam proses belajar mengajar sehingga berakibat rendahnya keterampilan menulis karangan pada siswa SDN 004 Langgini Bangkinang Kota. 
Agar pembelajaran menulis karangan dapat terlaksana dengan baik pada jenjang pendidikan SD, diperlukan guru yang terampil untuk merancang dan mengelola pembelajaran. Salah satu upaya yang dapat dilakukan oleh seorang guru dalam proses pembelajaran agar siswa lebih aktif dan kreatif dalam pembelajaran Bahasa Indonesia khususnya dalam meningkatkan keterampilan menulis karangan yaitu dengan menggunakan media gambar.

Agar proses pembelajaran berlangsung dengan baik, guru perlu mencari solusi bagaimana cara meningkatkan keterampilan menulis karangan siswa. Dengan cara menggunakan siswa melalui peragaan-peragaan atau media gambar maka para siswa akan cepat merespon dan memahami secara langsung sehingga proses pembelajaran antara guru dengan siswa akan lebih efektif. Untuk melaksanakan proses pembelajaran yang aktif, guru harus bisa menerapkan media bergambar yang bervariasi.

Oleh kerena itu, mengingat pentingnya pembalajaran Bahasa Indonesia dalam meningkatkan mutu pendidikan maka masalah di atas perlu diberikan alternatif pemecahan masalah oleh peneliti dengan menerapkan media bergambar. Karena dengan menggunakan media gambar dapat membantu siswa meningkatkan keterampilan menulis karangan dan siswa juga dapat melihat hubungan antara konsep, peristiwa, dan tokoh yang ada dalam pelajaran serta siswa dapat melihat hubungan antara komponenkomponen materi atau isi pelajaran yang diajarkan. Dengan bantuan media gambar, guru akan lebih mudah mengatasi gangguan yang akan menghambat proses pembelajran dan mengambil alih perhatian siswa di kelas.

Berdasarkan pembelajaran diatas, penelitian termotivasi dan mendapat inspirasi untuk melakukan peningkatan pembelajaran dengan tindakan kelas yang berjudul: "Peningkatan Keterampilan Menulis Karangan dengan Menggunakan Media Gambar pada Siswa Kelas V Sekolah Dasar.

\section{METODE}

Metode yang digunakan dalam penelitian ini adalah penelitian tindakan kelas (PTK). Menurut Arikunto (Siswanto \& Suyanto, 2017: 15) penelitian tindakan kelas (PTK) atau Classroom Action Research, yaitu penelitian yang dilakukan oleh guru ke kelas atau di sekolah tempat ia mengajar dengan penekanan pada penyempurnaan atau peningkatan proses dan praktis pembelajaran. Arikunto (Faizah, 2011:100) juga mengemukakan bahwa penelitian tindakan kelas merupakan suatu pencermatan terhadap kegiatan belajar berupa sebuah tindakan, yang sengaja dimunculkan dan terjadi dalam sebuah kelas secara bersama. Tindakan tersebut diberikan atau diarahkan oleh guru yang dilakukan oleh siswa.

Menurut Supardi (Siswanto \& Suyanto, 2017: 15) penelitian tindakan kelas merupakan suatu penelitian yang akar permasalahannya muncul di kelas, dan dirasakan langsung oleh guru yang bersangkutan, sehinga sulit dibenarkan jika ada yang menyebutkan bahwa permasalahan dalam penelitian tindakan kelas diperoleh dari persepsi atau lamunan seorang peneliti itu sendiri.

penelitian tindakan kelas merupakan penelitian yang dilakukan oleh guru yang subjeknya seluruh siswa didalam kelas tersebut dengan tujuan untuk memperbaiki atau meningkatkan proses pembelajaran (Marta, R, 2018: 82).

Penelitian dilakukan dengan jalan merancang, melaksanakan dan merefleksikan tindakan secara kolaboratif dan partisipatif yang bertujuan untuk memperbaiki proses 
pembelajaran di kelas melalui suatu tindakan dalam suatu siklus (Fadhilaturrahmi, 2017a dalam (Ananda, 2018).

Penelitian ini dilaksanakan dalam beberapa siklus, yang terdiri dari dua siklus. siklus I terdiri dari perencanaan, pelaksanaan, pengamatan, refleksi, dan siklus ke II juga demikian terdiri dari perencanaan pelaksanaan, pengamatan, dan refleksi.

Adapun siklus PTK menurut Siswanto dan Suyanto (2017: 11-12) adalah sebagai berikut:

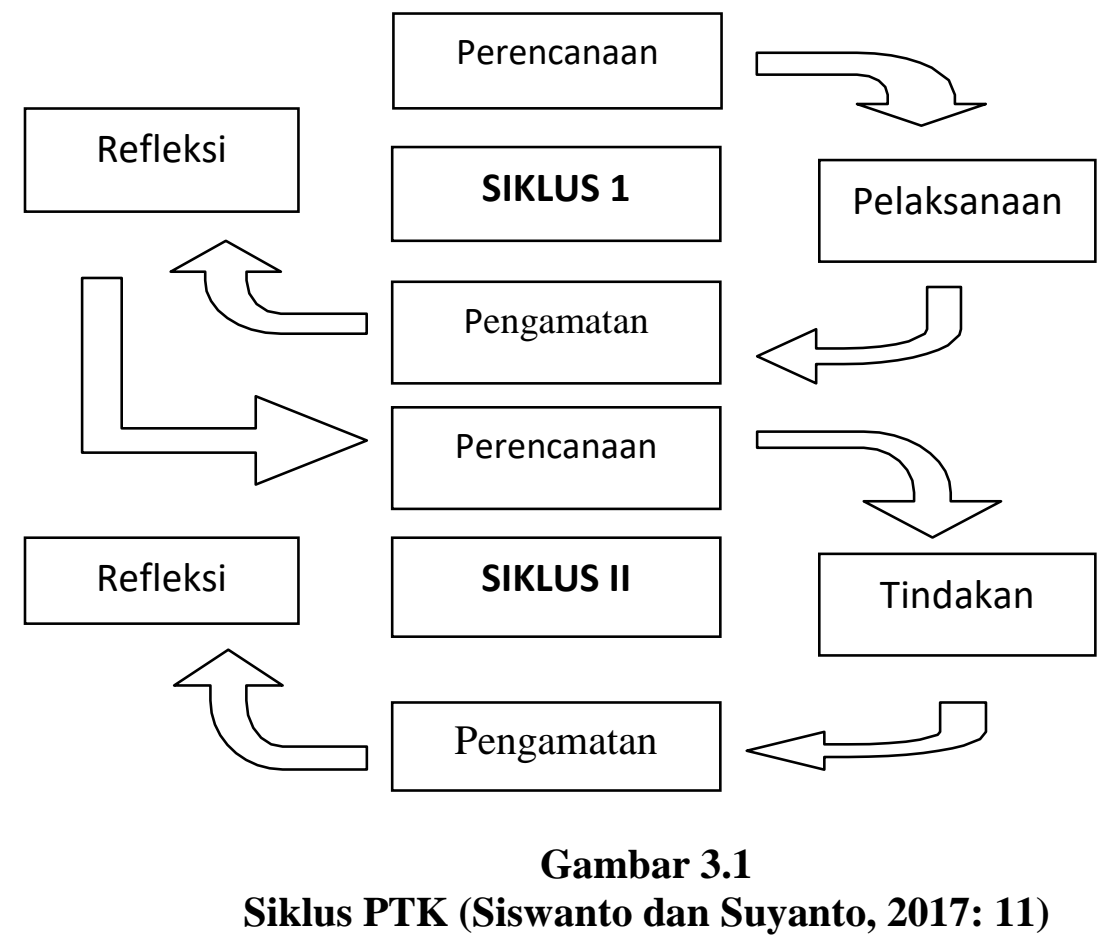

\section{a. Perencanaan}

1. Menyusun silabus Rencana Pelaksnaan Pembelajaran (RPP) sesuai dengan indicator yang telah ditetapkan.

2. Menyiapkan media/ alat peraga yang digunakan dalam penelitian.

3. Menyiapkan alat dan evaluasi yang berupa lembar kerja siswa.

4. Menyiapkan lembar observasi dan berbagai instrumen pengumpulan data yang akan digunakan dalam penelitian.

\section{b. Pelaksanaan}

Pelaksanaan tindakan penelitian ini dibuat dalam dua siklus, dimana terdiri dari dua pertemuan. Siklus pertama dilaksanakan pembelajaran dengan menggunakan media gambar. Siklus kedua pelaksanaan pembelajaran tetap menggunakan media gambar dan berdasarkan hasil refleksi pada siklus pertama. Jika pada siklus kedua belum juga ada peningkatan, maka dilanjutkan dengan siklus berikutnya.

\section{c. Observasi}

Observasi (pengamatan) dilaksanakan selama penelitian berlangsung. Kegiatan observasi meliputi pengamatan terhadap pelaksanaan pembelajaran, mencatat apa saja kegiatan yang dilakukan siswa dikelas dan melihat apa saja yang menjadi hambatan saat pembelajaran berlangsung.

\section{d. Refleksi}


Pada tahap ini, peneliti menganalisis kekurangan dan kelebihan dari rancangan yang telah dilaksanakan. Apabila terdapat kekurangan, maka akan dijadikan sebagai bahan untuk membuat rancangan selanjutnya, sehingga tujuan pembelajaran tercapai sesuai dengan yang diinginkan. Refleksi dilakukan secara kolaboratif, yaitu adanya diskusi terhadap berbagai masalah yang terjadi dikelas penelitian.

\section{Teknik Analisis Data}

\section{Analisis Kualitatif}

Menurut arikunto dalam Yusnita (2017: 52) mengatakan bahwa analisis kualitatif adalah data yang digambarkan dengan kata-kata atau kalimat dipisah-pisahkan menurut kategori yang memperoleh kesimpulan. Data kualitatif dalam penelitian ini digunakan untuk mendeskripsikan proses pembelajaran dengan menggunakan media gambar.

\section{Analisis Kuantitatif}

Data kuantitatif dalam penelitian ini digunakan untuk mengukur aktivitas belajar siswa. Aktivitas belajar terdiri dari kreativitas secara individu dari presentase aktivitas siswa. Setelah data terkumpulkan melalui observasi dan dokumentasi, data aktivitas siswa diolah dengan menggunakan rumus prensentase, yaitu sebagai berikut:

$$
\mathrm{P}=\frac{\mathrm{F}}{\mathrm{N}} \mathrm{X} 100 \%
$$

Keterangan:

$\mathrm{F}=$ Frekuensi yang sedang dicari presentasenya

$\mathrm{N}=$ Frekuensi/jumlah banyaknya individu

$\mathrm{P}=$ Angka prensentase

$100=$ Bilangan tetap

Dalam menentukan kriteria penilaian tentang hasil penelitian, maka dilakukan pengelompokkan atas 5 kriteria penelitian yaitu baik sekali, baik, cukup, kurang sekali. Adapun kriteria persentase tersebut yaitu sebagai berikut:

\section{Tabel 3.1 Kriteria Penggolongan Aktivitas Belajar Siswa}

\begin{tabular}{|c|c|c|}
\hline NO & $\begin{array}{c}\text { Skor Rata-rata } \\
\text { Aktivitas Belajar }\end{array}$ & Kategori \\
\hline 1 & $80 \%-100 \%$ & Baik sekali \\
\hline 2 & $70 \%-79 \%$ & Baik \\
\hline 3 & $60 \%-69 \%$ & Cukup \\
\hline 4 & $50 \%-59 \%$ & Kurang \\
\hline 5 & $0 \%-49 \%$ & $\begin{array}{c}\text { Sangat } \\
\text { kurang }\end{array}$ \\
\hline
\end{tabular}

Sumber: Arikunto (Yusnita, 2017:29)

Untuk menghitung keberhasilan belajar siswa klasikal digunakan rumus:

Jumlah siswa yang tuntas belajar

$$
\text { Ketuntasan Klasikal }=\frac{\text { Jumlah seluruh siswa }}{\text { X 100\% }}
$$

Ketuntasan klasikal jika $\geq 80 \%$ siswa udah mencapai ketuntasan belajar (KKM) Triyanto (2010: 124). KKM pada mata pelajaran Bahasa Indonesia di SDN 004 Bangkinang Kota adalah $\leq 75 \%$. 


\section{HASIL DAN PEMBAHASAN}

\section{Perencanaan Pembelajaran Bahasa Indonesia dengan Menggunakan Media Gambar}

Pada perencanaan siklus I dan siklus II pembelajaran Bahasa Indonesia dengan materi tema organ gerak manusia dan hewan, pada siswa kelas V SDN 004 Langgini Bangkinang Kota, peneliti harus menyiapkan perencanaan pembelajaram karena proses pembelajaran perlu direncanakan, adapun perencanaan yang dilakukan oleh peneliti dalam peneliti ini yaitu: menyusun instrumen berupa silabus, menyusun RPP dengan menggunakan media gambar, menyiapkan lembar observasi aktivitas guru dan siswa, Lembar Tugas Siswa, menerima guru kelas V menjadi Observer siswa, dan meminta teman sejawat untuk menjadi observer siswa.

Adapun komponen-komponen penting yang ada dalam rencana pembelajaran meliputi: identitas, standar kompentensi (KD), indikator, tujuan pembelajaran, materi pokok, pembelajaran dengan menggunakan media gambar, langkah-langkah pembelajaran, sumber pembelajaran, dan penilaian. Standar kompetensi pembelajarannya adalah Menentukan ide pokok bacaan, menulis dan mengembangkan ide pokok menjadi paragraf.

Pada siklus I, setelah melalui proses perencanaan pembelajaran hingga terlaksana pembelajaran di kelas dengan menggunakan media gambar untuk meningkatkan keterampilan menulis karangan siswa. Jika menulis karangan siswa belum terlaksana dengan baik maka perlu perencanaan yang lebih baik pada siklus II.

Jadi, setelah dilaksanakan tindakan dengan menggunakan media gambar dan diamati oleh observer siklus I, maka penelitian akan menyiapkan perencanaan pembelajaran pada siklus II sehingga tujuan dari menulis karangan dapat tercapai. Sebelum melaksanakan tindakan, peneliti akan menyiapkan gambar untuk memberikan apersepsi pada siswa yang sesuai dengan materi yang sedang diajarkan dan mudah dipahami oleh siswa. Kemudian memisahkan letak bahan ajar, lembar tugas siswa dan gambar sehingga ketika masuk kelas peneliti sudah siap untuk mengajar.

\section{Proses Pembelajaran Bahasa Indonesia dengan Menggunakan Media Gambar}

Berdasarkan hasil pelaksanaan pada siklus I, pembelajaran masih tergolong rendah kerana saat guru memberikan apersepsi siswa kurang antusias dan tidak fokus pada gambar, dalam menyampaikan motivasi dan tujuan pembelajaran siswa masih ada yang bercerita dengan teman sebangkunya dan tidak mendengarkan. Begitu juga siswa yang memperlihatkan kemampuannya walaupun suka bercerita tapi berusaha untuk bertanya sesuai perintah guru. Menurut Kusnandi dan Sujtipto (2013:41-42) media gambar adalah media yang berfungsi untuk menyampaikan pesan melalui gambar yang menyangkut indera penglihatan. Pesan yang disampaikan dituangkan melalui simbolsimbol komunikasi visual. Media gambar mempunyai tujuan untuk menarik perhatian memperjelaskan materi, menghilustrasikan fakta dan informasi. Jika diberi kesempatan untuk mengembangkan sendiri, masih ada siswa yang bercerita karena sebelumnya belum terbiasa merumuskan pertanyaan sehingga sistematik yang akan dibentuk tidak berjalan dengan lancar.

Selain kelemahan itu yang didapatkan dari siswa, maka pendidikpun berperan penting dlam suksesnya sesuatu pembelajaran. Ini terjadi katika guru kurang membimbing siswa dlam membaca wacana sehingga ada siswa yang membaca keras dan ada yang membaca dalam hati. Dalam mengajar guru belum membimbing siswa 
seperti apa pembelajaran yang sedang berlangsung. Karena siswa itu adalah hal baru dan berbeda dari pembelajaran sebelumnya. Menurut Rahmawatiningsih (2010:5) menyatakan bahwa dengan menggunakan media gambar dapat membantu menyajikan suatu kejadian peristiwa yang kronologis dengan menghadirkan orang, benda, dan latar. Kronologis atau urutan peristiwa dapat memudahkan siswa untuk menuangkan idenya dalam kegiatan bercerita. Jadi, pada siklus I guru belum menggunakan media gambar ini dengan baik sehingga diperbaikan pada siklus II dengan pembimbing siswa bagaimana proses pembelajaran yang akan terjadi. Dengan kurangnya bimbingan guru tentang proses pembelajaran yang sehingga juga berpengaruh pada pengelolaan kelas yang masih kurang sehingga proses pembelajaran menggunakan media gambar masih belum berjalan dengan semestinya.

Pada siklus II ini sudah terlaksana dengan baik, karena siswa sudah bisa melaksanakan pembelajaran sesuai dengan cara kerja menggunakan media gambar, siswa telah memperhatikan dan mendengarkan tujuan pembelajaran yang disampaikan oleh guru. Siswa mendengarkan penjelasan yang di sampaiakn oleh guru sehingga siswa memahami dan aktif dalam belajar, siswa dengan mudah mengerjakan tugas yang diberikan oleh guru. Guru telah mengatur waktu dengan baik, sehingga dapat membimbing siswa untuk menyimpulkan pembelajaran secara keseluruhan. Dengan penguasaan kelas yang baik maka mempengaruhi hasil keterampilan menulis karangan siswa yang ditandai dengan siswa sudah sangat baik dalam mengemukakakan ide dalam menulis karangan, sistem penulisan siswa sudah benar, karangannya tidak bertele-tele lagi, penggunaan bahasanya juga sudah baik dan dalam memilih judul karangan juga sudah tepat sesuai dengan gambar yang diamati oleh siswa.

Berdasarkan hasil pelaksanaan pada siklus I dan siklus II, dapat dinyatakan bahwa pembelajaran di kelas V SDN 004 Langgini Bangkinang Kota menggunakan media gambar dapat meningkatkan keterampilan menulis karangan siswa kelas V SDN 004 Langgini Bangkinang Kota.

\section{Peningkatan Keterampilan Menulis Karangan Siswa dengan Menggunakan Media Gambar}

Dari hasil kegiatan selama penelitian dengan menggunakan media gambar memiliki kelemahan dan kelebihan masing-masing yang tercipta dari proses pembelajaran yang sedang berlangsung. Karena dipengaruhi oleh pengelolaan kelas yang dilakukan guru. Karena siswa yang awalnya hanya sabagai pendengar dan sekarang dihadapkan pada situasi untuk mengajak mengarang sebuah karangan sendiri sehingga membutuhkan proses untuk berubah. Maka proses keterampilan menulis karangan oleh Abbas (2006:125) tentang kemampuan mengungkapkan gagasan, pendapat dan perasaan pada pihak lain dengan melalui bahasa tulis. Pada siklus I ini ada 9 orang siswa dengan persentase $52 \%$. Kemudian pada siklus II peneliti mempelajari apa kelemahan pada siklus I karena pada pengelolaan kelas masih kurang dan masih banyak siswa yang belum fokus. Sehingga pada siklus II siswa yang tuntas ada 14 orang siswa yang dengan persentase $82 \%$.

Peningkatan proses belajar siswa dari keseluruhan pada siklus I yaitu $71,76 \%$ siswa yang sudah tuntas dalam keterampilan menulis karangan. Pada siklus I ini ada 9 orang siswa yaitu AT, AD, GF, FR, FJ, QS, ID, dan MI. Jika dilihat dari hasil proses belajar siswa pada siklus I proses belajar siswa masih tergolong rendah, hal ini disebababkan karena pada siklus I masih banyak siswa yang tidak memperhatikan dan mendengar tujuan pembelajaran yang disampaikan oleh guru, tingkat keaktifan siswa masih kurang, 
maka dari kekurangan-kekurangan tersebut harus diperbaiki agar tidak terjadi pada siklus selanjutnya, perbaikan ini harus dilakukan dengan cara guru harus membuat siswa tertarik dengan pembelajarn yang diajarkan oleh guru agar meningkatkan keaktifan siswa saat belajar.

Hasil perolehan hasil belajar siswa pada siklus II mengalami peningkatan jika dibandingkan dengan sikls I. Siswa yang aktif secara keseluruhan yaitu 80,94\%. Siswa yang tuntas dalam keterampilan menulis karangan pada pertemuan siklus II ada 14 orang siswa yaitu AT, AF, CT, GF, FR, FJ, FR, QS, ID, KR, MH, NB, dan Melsya. Hasil proses belajar siswa telah mencapai indikator keberhasilan yaitu $80 \%$. Dengan demikian dapat disimpulkan bahwa proses belajar siswa mengalami peningkatan dengan menggunakan media gambar. Jadi, hasil analisis ini mendukung hipotesis tindakan yang diajukan yaitu "Peningkatan Keterampilan Menulis karangan Dengan Menggunakan Media Gambar Pada Siswa Kelas V SDN 004 Langgini Bangkinang Kota.

\section{SIMPULAN}

\section{Simpulan}

Berdasarkan hasil penelitian yang telah dilaksanakan selama dua siklus dengan menggunakan media gambar untuk menigkatkan keterampilan menulis karangan pada siswa Kelas V SDN 044 Langgini Bangkinang Kota.

\section{Perencanaan Pembelajaran Menulis Karangan Dengan Menggunakan Media Gambar}

Berdasarkan hasil penelitian dan kesimpulalajaran, maka proses pembelajaran dengan menggunakan media gambar dan diamati observer pada siklus 1, maka penelitian akan melakukan refleksi pada perencanaan pembelajaran pada siklus II sehingga tujuan dari keterampilan menulis karangan dapat tercapai. Peneliti juga mempelajari apa kelebihan dan kelemahan yang telah terjadi di kelas sehingga pada saat tindakan di siklus II guru bisa merencanakan untuk membimbing siswa menggunaka media gambar pada saat proses belajar mengajar.

\section{Proses Pembelajaran Bahasa Indonesia dengan Menggunakan Media Gambar.}

Berdasarkan hasil pelaksanaan pada siklus I, karena masih terdapat kelemahan dalam penerapan menggunakan media gambar ini. Jika diberi kesempatan untuk mengembangkan sendiri, masih ada siswa yang bercerita karena sebelumnya belum terbiasa merumuskan pertanyaan sehingga sistematik yang akan dibentuk tidak berjalan dengan lancar. Pada siklus II ini sudah terlaksana dengan baik, karena siswa sudah bisa melaksanakan pembelajaran sesuai dengan cara kerja dengan menggunakan media gambar. Kemudian siswa telah memperhatikan dan mendengarkan tujuan pembelajaran yang disampaikan oleh guru. Siswa mendengarkan penjelasan yang di sampaikan oleh guru sehingga siswa memahami dan aktif dalam belajar, siswa dengan mudah mengerjakan tugas yang diberikan oleh guru.

Setelah itu, guru sudah mengatur waktu dengan baik, sehingga dapat membimbing siswa untuk menyimpulkan pembelajaran secara keseluruhan. Dengan penguasaan kelas yang baik maka mempengaruhi hasil keterampilan menulis karangan siswa yang ditandai dengan siswa sudah sangat baik dalam mengemukakakan ide dalam menulis karangan, sistem penulisan siswa sudah benar, karangannya tidak bertele-tele lagi, 
penggunaan bahasanya juga sudah baik dan dalam memilih judul karangan juga sudah tepat sesuai dengan gambar yang diamati oleh siswa.

\section{Peningkatan Keterampilan Menulis karangan siswa dengan Menggunakan Media Gambar}

Dari hasil kegiatan selama penelitian dengan menggunakan media gambar memiliki kelemahan dan kelebihan masing-masing yang tercipta dari proses pembelajaran yang sedang berlangsung. Karena dipengaruhi oleh pengelolaan kelas yang dilakukan guru. Karena siswa yang awalnya hanya sabagai pendengar dan sekarang dihadapkan pada situasi untuk mengajak mengarang sebuah karangan sendiri sehingga membutuhkan proses untuk berubah. Pada siklus I ini ada 9 orang siswa dengan persentase $52 \%$. Kemudian pada siklus II peneliti mempelajari apa kelemahan pada siklus I karena pada pengelolaan kelas masih kurang dan masih banyak siswa yang belum fokus. Sehingga pada siklus II siswa yang tuntas ada 14 orang siswa yang dengan persentase $82 \%$.

Adapun hasil tes keterampilan menulias karangan di kelas V SDN 004 Langgini Bangkinang Kota pada siklus I mendapatkan hasil 71,05\%. Secara keseluruhan siswa yang sudah tuntas dalam keterampilan menulis karangan pada siklus ini ada 9 orang siswa yaitu AT, AD, GF, FR, FJ, QS, ID, dan MI. Kemudian pada siklus II keterampilan menulis karangan siswa mengalami peningkatan $80,94 \%$ dan hal ini dapat dikategorikan sangat baik. Siswa yang tuntas dalam keterampilan menulis karangan pada pertemuan ini ada 14 orang siswa yaitu: AT, AD, CT, GF, FRi, FJ, FA, QS, ID, KR, MI, M.Habil, NB, dan ML. Dari hasil setiap siklus dapat diperoleh kesimpulan bahwa untuk meningkatkan keterampilan menulis karangan pada kelas V SDN 004 Bangkinang Kota dapat menggunakan media gambar sebagai proses pembelajaran siswa.

\section{Saran}

Berdasarkan hasil penelitian yang telah dilakukan maka saran penulis yang berhubungan dengan penelitian ini adalah sebagai berikut:

1. Bagi guru, dalam menggunakan media gambar diharapkan membiasakan siswa belajar melalui kelompok agar keterampilan menulis karangan siswa meningkat. Guru juga diharapkan untuk memperhitungkan pembagian waktu dengan tepat dan cukup agar siswa memiliki waktu yang cukup untuk meningkatkan menulis karangan siswa. Selain itu, guru diharapkan memberikan soal-soal meningkatkan keterampilan menulis karangan siswa.

2. Bagi sekolah, agar dapat meningkatkan keterampilan manulis karangan dan menjadi acuan pembelajaran dengan menggunakan media gambar dan media lainnya sperti video, agar dapat memfasilitasi guru agar bisa menambah pengetahuan dan motivasi guru untuk bisa meningkatkan keterampilan menulis karangan siswa. Sekolah juga harus mengawasi kegiatan guru dikelas karena tidak semua guru menggunakan jam pelajaran dengan benar.

3. Bagi peneliti selanjutnya yang tertarik meneliti keterampilan menulis karangan siswa agar menambah observer lebih dari satu orang karena yang diamati itu proses pembelajaran dan data yang diperoleh lebih valid. Untuk mengumpulkan data yang lebih valid lagi sebaiknya ketika mengajar harus divideokan dari awal sampai akhir.

\section{DAFTAR PUSTAKA}


Abbas, S. (2006). Pembelajaran Bahasa Indonesia Yang Efekti Di Sekolah Dasar. Jakarta: Departemen Pendidikan Nasional.

Ananda, R. (2018). Peningkatan Pembelajaran PKn dengan Penerapan Metode Role-Playing Siswa Kelas II SDN 003 Bangkinang Kota. Jurnal Basicedu Volume 2 Nomor 1 Tahun 2018 Halaman 37.

Arsyad. (2016). Media Pembelajaran. Jakarta: PT Rajagrafindo Persada.

Astuti, Y. (2013). Peningkatan Keterampilan Menulis Karangan Narasi Menggunakan Model Experiential Learning Pada Siswa Kelas IV SDN Bangunjiwo Bantul. Universitas Negeri Yogyakarta: Skripsi tidak dipublikasikan.

Azlina. (2016). Peningkatan Keterampilan Menulis Karangan Narasi dengan Menggunakan Pendekatan CTL Siswa Sekolah Dasar. Bangkinang: Skripsi Tidak Dipublikasikan.

Azmussya'ni. (2014). Peningkatan Keterampilan Menulis Menggunakan Peningkatan Proses Dengan Media Gambar di SDN 3 Sakra. Jurnal Prima Edukasia, Volume 2- Nomor 1,2014

Ahsin, M.N. (2016) Peningkatan Keterampilan Menulis Karangan Narasi Dengan Menggunakan Media Audiovisual dan Metode Quantum Learning. Jurnal Refleksi Edukatika. Vol. 6 No. 2 Juni 2016.

Faizah, H. (2011). Menulis Karangan Ilmiah. Pekanbaru: Cendikia Insani.

Gie, TL. (2002). Pengantar dunia karang-mengarang. Yogyakarta: Liberty Yoyakarta.

Hamdani. (2011). Strategi Belajar Mengajar. Bandung: Pustaka Setia.

Hernawan, dkk. (2007). Media Pembelajaran Sekolah Dasar. Bandung: UPI PRESS.

Isneani, Nur Faizah. (2013). Penggunaan Media Kartu Bilangan Untuk Meningkatkan Motivasi Belajar Siswa. [Online]. Tersedia: http://lib.unnes.ac.id/1734/1401409066.pdf.[Diakses 20 maret 2018].

Juldianty. (2016). Peningkatan Keterampilan Menulis Narasi Melalui Penggunaan Media Gambar Seri Siswa Kelas III. Jurnal Pendidikan Dasar Volume 7 Edisi 2 Desember 2016

Keraf, G. (1994). Kompisisi. Jakarta: Nusa Indah.

Kusnandi, C. dan Sujtipto, B. (2013). Media Pembelajaran Manual dan Digital. Bogor: Ghalia Indonesia.

Lestari, G. (2014). Upaya Meningkatkan Kemampuan Mengarang Siswa Melalui Media Gambar Seri. Yogyakarta: Skripsi tidak dipublikasikan.

Mawarni, Rosdiana. (2015) Peningkatan Keterampilan Menulis Karangan Narasi Menggunakan Media Film Siswa Kelas III SDN Pencar 2, Selemen. Jurnal Pendidikan Guru Sekolah Dasar Edisi 15 Tahun ke IV Agustus 2015.

Mayer, RE. (2009). Mutimedia Prinsip-Prinsip dan Aplikasi. Yogyakarta: Pustaka Pelajar.

Mariana. (2017). Peningkatan Keterampilan Menulis Paragraf Melalui Penerapan Kegiatan Menulis Jurnal dan Pemanfaatnya Pada Siswa Kelas III MTS Negeri Kota Tering Tinggi. SEJ Volume 7 No. 1 Juni 2017.

Marta, R. (2018). Penerapan Model Kooperatif tipe Nominal Group untuk Meningkatkan Hasil Belajar Matematika di Kelas IV Sekolah Dasar. Jurnal Basicedu Volume 2 Nomor 1 Tahun 2018 Halaman 82.

Nurdin dan Adriantoni. (2016). Kurikulum dan Pembelajaran. Jakarta: Rajawali.

Nugraheni. (2012). Pengajaran Bahasa Indonesia Berbasis Karakter. Yogyakarta. Mentari Pustaka.

Rahardi, K. (2009). Bahasa Indonesia Untuk Perguruan Tinggi. Bandung: Erlangga.

Rahmawatiningsih, (2010). Media peendidikan. Jakarta: PT. Raja Grafindo Pustaka.

Syarif, dkk. (2009). Metodologi Penelitian Pendidikan. Jakarta: Pt Bumi Aksara.

Saputra dan Rudhyanto, (2005). Pembelajaran kooperatif untuk meningkatkan keterampilan anak TK. Jakarta: Depdiknas.

Sirait, dkk. (1985). Pedoman karang-mengarang. Jakarta: pusat pembinaan

Syah, M. (2005). Psikologi Belajar. Jakarta: Bumi Aksara.

Siswanto dan Suyanto, (2017). Metode Peneleitian Kombinasi Kualitatif dan Kuantitatif Pada Penelitian Tindakan (PTK Dan PTS). Klaten: Bossscript. 
Suprihatiningrum, J. (2016). Strategi Pembelajaran. Jogjakarta: Ar-Ruzz Media. Sudjana, N dan Rivai, A. (2013). Media Pembelajaran. Bandung: Sinar Baru Algensindo.

Sundayana, R. (2014). Media dan Alat Peraga Dalam Pembelajaran Matematika. Bandung: Alfabeta.

Saddhono, (2012). Meningkatkan Keterampilan Berbahasa Indonesia. Bandung: Karya Putra Darwai

Taufina, (2016). Mozaik Keterampilan Berbahasa di Sekolah Dasar. Bandung: CV Angkasa

Tarigan. (2008). Menulis Sebagai Suatu Keterampilan Berbahasa. Bandung: Angkasa.

Triyanto. (2007). Model Pembelajaran Terpadu dalam Teori dan Praktek. Jakarta : Tim Prestasi Pustaka.

Warsidi. 2009. Mengenal jenis Tulisan. Bandung: Putri Delcon.

Yulianti, R. (2016). Peningkatan Keterampilan Menulis Karangan Narasi Menggunakan Media Pop-Up Book Pada Siswa Kelas IV SD Negeri 2 Kedunglegok Kecamatan Kemangkon Kabupaten Purbalingga Tahun Ajaran 2015/2016. Universitas Negeri Yogyakarata: Skripsi tidak dipubikasikan.

Yusnita, E. (2017). Peningkatan Aktifitas Belajar Matematika dengan Menggunakan Pendekatan Scientific di Kelas IV Siswa Sekolah Dasar. Universitas Pahlawan Tuanku Tambusai Bangkinang: Skripsi tidak dipuplikasikan. 